\title{
ROUSSELIANONE A, NOVEL ANTIBIOTIC RELATED TO PHENALENONE PRODUCED BY Phaeosphaeria rousseliana
}

\author{
Jin-Zhong XiaO ${ }^{\dagger}$, Shigenori Kumazawa, Hirofumi Tomita, \\ Nobuji Yoshikawa, Chizuko Kimura and Takashi Mikawa* \\ Research Center, Mitsubishi Kasei Corporation, \\ Kamoshida-cho, Midori-ku, Yokohama 227, Japan
}

(Received for publication April 6, 1993)

\begin{abstract}
Novel antibiotic, rousselianone A, was produced by fermentation of Phaeosphaeria rousseliana L2144. Rousselianone A was characterized as a new derivative of phenalenone. The antibiotic showed no antimicrobial activity in vitro, but exhibited in vivo antifungal activity against plant diseases with a relatively broad spectrum.
\end{abstract}

In the course of our screening program for new antibiotics with fungicidal activity from microorganisms, a novel substance, rousselianone A, was discovered in the fermentation broth of Phaeosphaeria rousseliana L2144. The antibiotic exhibited in vivo antifungal activity against plant diseases. This report describes the taxonomy of the producing fungus, fermentation and isolation procedures as well as physico-chemical and biological properties of the antibiotic.

\section{Materials and Methods}

Culture and Medium Condition

The culture of $P$. rousseliana $\mathrm{L} 2144$ was inoculated from a potato dextrose agar slant into $200-\mathrm{ml}$ Erlenmeyer flasks containing $40 \mathrm{ml}$ of a medium consisting of malt extract $3.5 \%$, corn starch $3 \%$, corn steep liquor $1.5 \%$, pharmamedia (Traders Oil Mill Co., Texas) $1.5 \%$, soluble vegetable protein $0.5 \%$, $\mathrm{CaCO}_{3} 0.2 \%$ (pH 6.0 before sterilization). The culture was incubated on a rotary shaker at $210 \mathrm{rpm}$ for 4 days at $27^{\circ} \mathrm{C}$. Four $\mathrm{ml}$ of the seed culture were inoculated into each of one hundred $500-\mathrm{ml}$ Erlenmeyer flasks containing $80 \mathrm{ml}$ of the same medium. The culture was continued under the same condition as listed above for another 4 days.

In vivo Fungicidal Activity

Preventive activity of the antibiotic isolated against plant diseases was investigated in pot tests. An aqueous solution of compounds (containing $4 \%$ acetone) at appropriate concentrations was applied to potted seedlings of rice (Oryza sativa var. Akinishiki), wheat (Triticum aestivum var. Norin No. 61), cucumber (Cucumis sativus var. Suyoh) and tomato (Lycopersicum esculentum var. Red cherry). After air drying the liquid chemical, the spore suspensions of Pyricularia oryzae (Magnaporthe grisea, the causal agent of rice blast) cultured on oat-meal agar medium, Puccinia recondita (causal agent of wheat brown rust) harvested from infected wheat leaves, Botrytis cinerea (causal agent of cucumber grey mold) cultured on potato dextrose agar medium, Phytophthora infestans (causal agent of tomato late blight) harvested from infected tomato leaves, or the mycelial suspension of Rhizoctonia solani (Thanatephorus cucumeris, causal agent of rice sheath blight) cultured in a yeast glucose medium was sprayed on the seedlings of respective hosts. The inoculated seedlings were kept in a moist chamber for $24 \sim 40$ hours and then maintained in a greenhouse until disease appearance. The protective value was calculated from the following

+ Present address: Microbial Toxicology Laboratory, The Institute of Physical and Chemical Research (RIKEN), Wako-shi, Saitama 351-01, Japan. 
formula: protective value $(\%)=\{(\mathrm{A}-\mathrm{B}) / \mathrm{A}\} \times 100$; where $\mathrm{A}$ is the total number of lesions or disease rate on untreated plants and $B$ is that on treated plants.

Antimicrobial Activity

Antimicrobial activity was determined in an agar dilution method in a YA medium (containing yeast extract $0.55 \%$ and agar $2 \%$ ) for bacteria and a PYGA medium (containing Polypeptone $0.55 \%$, yeast extract $0.27 \%$, glucose $0.55 \%$ and agar $1.65 \%$ ) for fungi. The MIC was expressed in term of $\mu \mathrm{g} / \mathrm{ml}$ after overnight incubation at $37^{\circ} \mathrm{C}$ for bacteria and 48 hours incubation at $27^{\circ} \mathrm{C}$ for fungi and yeasts.

\section{Instruments}

NMR spectra were recorded on a Bruker AM500 spectrometer with TMS as internal standard. Fast atom bombardment (FAB) mass spectra were obtained on a JEOL JMS-HS100 spectrometer. Electron impact (EI) mass spectra were recorded on Hitachi M-80A spectrometer. UV spectra were obtained on a Shimadzu UV-3100S spectrometer. IR spectra were recorded on a JASCO FT/IR-8000 spectrometer. Optical rotation was measured with a JASCO DIP-370 polarimeter.

\section{Results}

Taxonomy of the Producing Fungus

The producing fungus, strain L2144, was isolated from a dead culm of graminicolous plant collected at Anamizu-cho, Noto Peninsula, Japan, 1989. The identification of the strain L2144 was made with the help of monographs given by L. Holm ${ }^{1)}$, G. A. Hedjaroude ${ }^{2)}$ and A. L. LeuChtmann ${ }^{3)}$.

\section{Morphological Characteristics}

Pseudothecia, scattered or gregarious, immersed beneath the sheaths, globose to subglobose, $150 \sim 180 \mu \mathrm{m}$ in diameter, covered with brown hyphae. Ostiolar neck not distinctly differentiated. Pseudothecial walls thin, soft, composed of $3 \sim 4$ layers of polygonal cells. Asci numerous, mostly cylindrical, with short-stalked, $54.7 \sim 65.6 \mu \mathrm{m} \times 9.3 \sim 11.0 \mu \mathrm{m}, 8$ spored, bitunicate, thickened above, pseudoparaphysate. Ascospores, biseriate, ellipsoid to fusoid, ends obtuse, $20.3 \sim 23.0 \mu \mathrm{m} \times 4.7 \mu \mathrm{m}$, yellowish brown, 5 septate, the second cell slightly thicker than the other cells, smooth.

\section{Physiological Properties}

Growing temperature on PDA (potato dextrose agar) for 10 days: $10 \sim 30^{\circ} \mathrm{C}$. Optimum growing temperature: $27^{\circ} \mathrm{C}$. Growing $\mathrm{pH}$ on LcA (glucose $0.1 \%, \mathrm{KH}_{2} \mathrm{PO}_{4} 0.1 \%, \mathrm{MgSO}_{4} \cdot 7 \mathrm{H}_{2} \mathrm{O} 0.02 \%, \mathrm{KCl} 0.02 \%$, $\mathrm{NaNO}_{3} 0.2 \%$, yeast extract $0.02 \%$, agar $1.3 \%, \mathrm{pH} 6.5 \sim 7.0$ before sterilization): 3 to 9 . Optimum growing pH: $5 \sim 7$.

The above morphological characteristics of the producing strain revealed that this fungus belonged to the genus Phaeosphaeria Miyake in the Pleosporacece, the Loculoascornycetes. According to the monographs of Phaeosphaeria by L. Holm ${ }^{1)}$, G. A. Hedjaroude ${ }^{2)}$ and A. L. LeuChtmanN ${ }^{3)}, 21$ species are described under the genus Phaeosphaeria. These species are identified by specificity of host plants; differences in size, shape and cell numbers of ascospors; and the presence or absence of swollen cells of ascospores. The morphological characteristics of the producing strain L2144 fall within the limits of variability of Phaeosphaeria rousseliana (Desm.) Holm. Therefore, the strain L2144 was identified as Phaeosphaeria rousseliana. 
Isolation

The harvested culture broth was centrifuged to separate the culture fluid ( $\sim 6$ liters $)$ and mycelial cake. The mycelial cake was extracted with 4 liters methanol. Methanol was removed by filtration and the mycelial cake was extracted twice, each time with 3 liters of ethyl acetate. The organic layer was combined and then concentrated to yield $27 \mathrm{~g}$ of crude residue. The residue was dissolved in chloroform and subjected to silica gel column chromatography. The column was eluted with chloroform - petroleum ether - acetic acid $(10: 5: 1)$. The active fractions were collected and concentrated to dryness in vacuo to give a crude oil $(10 \mathrm{~g})$. The oil was dissolved in chloroform-methanol $(1: 1)$ and further applied to Sephadex LH-20 column chromatography. The column was eluted with chloroform-methanol $(1: 1)$. The active fractions were concentrated under reduced pressure and dissolved in a small amount of methanol. Yellowish green crystals $(5.5 \mathrm{~g})$ were obtained from the methanol solution. The crystals were dissolved in acetonitrile and further separated by preparative HPLC using an ODS column $(2 \times 15 \mathrm{~cm}$, Waters) with a mobile phase of acetonitrile - water $(70: 30)$. Active fractions were collected and concentrated in vacuo to yield purified rousselianone A $(2.2 \mathrm{~g})$.

\section{Physico-chemical Properties}

Rousselianone A was obtained as yellowish green crystals. The UV spectrum of rousselianone A showed intensely maximum absorption at 219,256 and $332 \mathrm{~nm}$ indicating the presence of a strongly conjugated function in the molecule. The IR spectrum of rousselianone A showed an $\mathrm{OH}$ stretch at $3400 \mathrm{~cm}^{-1}$, and an absorption band at $1600 \mathrm{~cm}^{-1}$ due to olefinic functions.

Rousselianone A is easily soluble in chloroform, ethyl acetate and acetonitrile, slightly soluble in methanol and dimethyl sulfoxide, but insoluble in water and hexane. It is unstable to light and temperature. Conversion of rousselianone $\mathrm{A}$ to another substance, rousselianone $\mathrm{A}^{\prime}$, occurred when rousselianone $\mathrm{A}$ was dissolved in acetone, especially in the presence of a small amount of acetic acid. Rousselianone $A^{\prime}$ isolated as pale yellow crystals, is stable to light and temperature. Rousselianone $\mathrm{A}^{\prime}$ was also obtained during the isolation of rousselianone $\mathrm{A}$ from culture broth when acetone was used as solvents.

Table 1 summarizes the chemical shifts observed on the ${ }^{1} \mathrm{H}$ and ${ }^{13} \mathrm{C}$ NMR spectra of rousselianone $\mathrm{A}$ and $\mathrm{A}^{\prime}$. The other physico-chemical properties are shown in Table 2 . The structures of rousselianone

Table $1 .{ }^{13} \mathrm{C}$ and ${ }^{1} \mathrm{H}$ NMR chemical shifts of rousselianone $\mathrm{A}$ and $\mathrm{A}^{\prime}$ in $\mathrm{CDCl}_{3}(\delta: \mathrm{ppm})$.

\begin{tabular}{|c|c|c|c|c|c|c|c|c|c|}
\hline \multirow{2}{*}{ No. } & \multicolumn{2}{|c|}{ Rousselianone A (1) } & \multicolumn{2}{|c|}{ Rousselianone $A^{\prime}$ (2) } & \multirow{2}{*}{ No. } & \multicolumn{2}{|c|}{ Rousselianone A (1) } & \multicolumn{2}{|c|}{ Rousselianone $A^{\prime}(2)$} \\
\hline & ${ }^{13} \mathrm{C}$ & ${ }^{1} \mathrm{H}$ & ${ }^{13} \mathrm{C}$ & ${ }^{1} \mathrm{H}$ & & ${ }^{13} \mathrm{C}$ & ${ }^{1} \mathrm{H}$ & ${ }^{13} \mathrm{C}$ & ${ }^{1} \mathrm{H}$ \\
\hline 1 & 194.5 & & 199.1 & & $9 \mathrm{a}$ & 105.7 & & 105.5 & \\
\hline 2 & 90.0 & & 77.4 & & $1^{\prime}$ & 66.8 & $4.68(2 \mathrm{H}, \mathrm{m})$ & 66.3 & $4.65(2 \mathrm{H}, \mathrm{m})$ \\
\hline 3 & 192.8 & & 197.1 & & $2^{\prime}$ & 117.8 & $5.55(1 \mathrm{H}, \mathrm{dd})$ & 117.7 & $5.52(1 \mathrm{H}, \mathrm{dd})$ \\
\hline $3 a$ & 101.8 & & 101.8 & & $3^{\prime}$ & 139.9 & & 139.8 & \\
\hline $3 b$ & 137.6 & & 137.1 & & $4^{\prime}$ & 18.4 & $1.80(3 \mathrm{H}, \mathrm{s})$ & 18.3 & $1.80(3 \mathrm{H}, \mathrm{s})$ \\
\hline 4 & 169.0 & & 168.7 & & $5^{\prime}$ & 26.0 & $1.86(3 \mathrm{H}, \mathrm{s})$ & 25.7 & $1.86(3 \mathrm{H}, \mathrm{s})$ \\
\hline 5 & 97.0 & $6.36(1 \mathrm{H}, \mathrm{s})$ & 97.0 & $6.27(1 \mathrm{H}, \mathrm{s})$ & $1^{\prime \prime}$ & & & 51.9 & $3.26(2 \mathrm{H}, \mathrm{s})$ \\
\hline 6 & 165.9 & & 165.5 & & $2^{\prime \prime}$ & & & 205.5 & \\
\hline $6 a$ & 115.7 & & 113.7 & & $3^{\prime \prime}$ & & & 30.0 & $2.19(3 \mathrm{H}, \mathrm{s})$ \\
\hline 7 & 150.6 & & 150.0 & & $2-\mathrm{OH}$ & & & & $3.91(1 \mathrm{H}, \mathrm{brs})$ \\
\hline 7-Me & 26.8 & $2.77(3 \mathrm{H}, \mathrm{s})$ & 26.5 & $2.78(3 \mathrm{H}, \mathrm{s})$ & $4-\mathrm{OH}$ & & $12.88(1 \mathrm{H}, \mathrm{s})$ & & $13.20(1 \mathrm{H}, \mathrm{s})$ \\
\hline 8 & 119.3 & $6.76(1 \mathrm{H}, \mathrm{s})$ & 119.1 & $6.72(1 \mathrm{H}, \mathrm{s})$ & $9 . \mathrm{OH}$ & & $12.39(1 \mathrm{H}, \mathrm{s})$ & & $12.62(1 \mathrm{H}, \mathrm{s})$ \\
\hline 9 & 166.8 & & 166.4 & & & & & & \\
\hline
\end{tabular}


Table 2. Physico-chemical properties of rousselianone $\mathbf{A}$ and $\mathbf{A}^{\prime}$.

\begin{tabular}{|c|c|c|}
\hline & Rousselianone A (1) & Rousselianone $\mathrm{A}^{\prime}$ (2) \\
\hline Appearance & Yellowish green crystal & Pale yellow crystal \\
\hline Molecular formula & $\mathrm{C}_{19} \mathrm{H}_{18} \mathrm{O}_{7}$ & $\mathrm{C}_{22} \mathrm{H}_{22} \mathrm{O}_{7}$ \\
\hline $\operatorname{MS}(m / z)$ & $\begin{array}{ll}\text { FAB-MS: } & 341\left(\mathrm{M}+\mathrm{H}-\mathrm{H}_{2} \mathrm{O}\right)^{+}, \\
& 364\left(\mathrm{M}+\mathrm{Na}-\mathrm{H}_{2} \mathrm{O}\right)^{+}\end{array}$ & EI-MS: 398 \\
\hline \multicolumn{3}{|l|}{ Elemental analysis } \\
\hline Caled: & C 63.69, H 5.03 & C 66.33, H 5.53 \\
\hline Found: & C 63.40, H 5.30 & C 66.21, H 5.73 \\
\hline $\mathrm{MP}$ & $163 \sim 164^{\circ} \mathrm{C}$ & $149 \sim 150^{\circ} \mathrm{C}$ \\
\hline$[\alpha]_{D}^{25}$ & a & $+0.41(c 0.5, \mathrm{MeCN})$ \\
\hline $\begin{array}{l}\mathrm{UV} \lambda_{\max } \mathrm{nm}(\varepsilon) \\
\quad(\text { in } \mathrm{MeCH})\end{array}$ & $\begin{array}{l}219(30,200), 256(28,200) \\
\quad 332(19,700)\end{array}$ & $\begin{array}{l}218(47,800), 257(46,000) \\
\quad 331(24,300)\end{array}$ \\
\hline $\operatorname{IR} v_{\max } \mathrm{cm}^{-1}($ in $\mathrm{KBr})$ & $\begin{array}{l}3400 \sim 3150,2970,2930,1630 \\
1610,1455,1395,1380,1345 \\
1310,1200,1155,1040,950 \\
830\end{array}$ & $\begin{array}{l}3400,2970,2930,1705,1630 \\
1600,1460,1390,1380,1350 \sim \\
1310,1210,1170,1150,960 \\
830\end{array}$ \\
\hline Solubility & $\begin{array}{l}\text { Soluble in chloroform, ethyl } \\
\text { acetate and methanol; insoluble } \\
\text { in hexane and water }\end{array}$ & $\begin{array}{l}\text { Soluble in chloroform, ethyl } \\
\text { acetate and acetone; insoluble in } \\
\text { hexane, methanol and water }\end{array}$ \\
\hline
\end{tabular}

a Undetectable due to its deep color.

Fig. 1. Chemical structures of rousselianone $A(1)$ and $A^{\prime}(2)$<smiles>[R7]c1cc(C)c2c(OCC=C(C)C)cc([R])c3c2c1C(=O)C([R7])([13CH3])C3=O</smiles>

$1 \quad \mathrm{R}_{1}=\mathrm{R}_{2}=\mathrm{R}_{3}=\mathrm{OH}$

1a $\mathrm{R}_{1}=\mathrm{OH}, \mathrm{R}_{2}=\mathrm{R}_{3}=\mathrm{O}$

$2 \mathrm{R}_{1}=\mathrm{R}_{2}=\mathrm{OH}, \mathrm{R}_{3}=\mathrm{CH}_{2} \mathrm{COCH}_{3}$

$3 \quad \mathrm{R}_{1}=\mathrm{R}_{2}=\mathrm{R}_{3}=\mathrm{Ac}$

$\mathrm{A}$ and $\mathrm{A}^{\prime}$ were determined as 2,2,4,9-tetrahydroxy6-isopentenoxy-7-methyl- $1 H$-phenalene-1,3(2H)dione and 2-acetonyl-2,4,9-trihydroxy-6-isopentenoxy-7-methyl-1 $H$-phenalene-1,3(2H)-dione, respectively (Fig. 1), on the basis of chemical and spectral evidence and by comparison with the published data of phenalenone related substances ${ }^{4 \sim 7)}$, and the details will be reported elsewhere.

\section{Biological Properties}

\section{Antimicrobial Activity}

Rousselianone $\mathrm{A}$ and its acetone adduct, rousselianone $\mathrm{A}^{\prime}$, were devoid of antimicrobial activity when tested against the following microorganisms at $100 \mu \mathrm{g} / \mathrm{ml}$ : Staphylococcus aureus, Micrococcus luteus, Bacillus subtilis, Clavibacter michiganens,
Table 3. Preventive activity of rousselianone A against several plant diseases.

\begin{tabular}{lccc}
\hline & \multicolumn{3}{c}{ Protective value (\%) } \\
\cline { 2 - 4 } $\begin{array}{l}\text { Diseases } \\
\text { (Pathogens) }\end{array}$ & \multicolumn{3}{c}{ Concentration $(\mu \mathrm{g} / \mathrm{ml})$} \\
\cline { 2 - 4 } & 250 & 50 & 10 \\
\hline $\begin{array}{l}\text { Rice blast } \\
\text { (Pyricularia oryzae) }\end{array}$ & 88 & 53 & 32 \\
$\begin{array}{l}\text { Rice sheath blight } \\
\text { Rhizoctonia solani) }\end{array}$ & 55 & 45 & 0 \\
$\begin{array}{l}\text { Wheat brown rust } \\
\text { (Puccinia recondita) }\end{array}$ & 89 & 60 & 19 \\
$\begin{array}{l}\text { Cucumber grey mold } \\
\text { (Botrytis cinerea) }\end{array}$ & 100 & 99 & 81 \\
$\begin{array}{l}\text { Tomato late blight } \\
\text { (Phytophthora infestans) }\end{array}$ & 86 & 48 & 0 \\
\hline
\end{tabular}


Escherichia coli, Pseudomonas aeruginosa, Klebsiella pneumoniae, Xanthomonas oryzae, Saccaromyces cerevisiae, Botrytis cinerea, Pyricularia oryzae, Alternaria mali, Aspergillus niger, Fusarium oxysporum, Glomenella cingulate.

\section{Preventive Activity Against Plant Pathogens}

As shown in Table 3, rousselianone A exhibited a marked antifungal activity against several plant diseases, especially to grey mold caused by Botrytis cinerea. Rousselianone $\mathrm{A}^{\prime}$ did not show such activity.

\section{Discussion}

A novel antibiotic, rousselianone $\mathrm{A}$, characterized as a derivative of phenalenone with an unusual 2,2-dihydroxy function in the structure was isolated by fermentation of Phaeosphaeria rousseliana L2144. Three groups of natural products with phenalenone skeleton have been reported to date: 1) Atrovenetin and herqueinone as well as their derivatives produced as pigments by Penicillium atrovenetum, $P$. herquei and Apergillus silvaticus ${ }^{6 \sim 11)}$; 2) sclerodin and its derivatives produced by plant pathological fungus Gremmeniella abietina ${ }^{5,12)}$; and 3) FR-901235, an immunoactive substance produced by Paecilomyces carneus $^{4)}$. No or only minor biological activity has been reported to these substances except for FR-901235, a derivative with 2-acetonyl-2-hydroxy in the structure. Rousselianone A was not active when tested for antimicrobial activity in vitro. However, a marked preventive activity against plant diseases in vivo was shown by rousselianone $\mathrm{A}$, but not by its acetone adduct, rousselianone $\mathrm{A}^{\prime}$. The in vivo activity of rousselianone $\mathrm{A}$ indicates a probable utility in agricultural industry. Further studies on action mode as well as other biological activities of rousselianone $A$ and $A^{\prime}$ are in progress.

\section{Acknowledgments}

We wish to express our thanks to Misses Yoshie Tsuruki and Sanae Sato in Research Center, Mitsubishi Kasei Corporation, for their technical assistance in the fungicidal tests.

\section{References}

1) Holm, T.: Etudes taxonomique sur les Pleosporacees, Symb. Bot. Upsal. 14: 1 188, 1957

2) Hadjaroude, G. A.: Etudes taxonomiques sur les Phaeoshaeria Miyake et leurs forms voisines (Ascomycetes). Sydowia 22: $57 \sim 107,1968$

3) Leuchtmann, A.: Uber Phaeosphaeria Miyake und andere bitunicate Ascomycen mit mehrfach querseptierten Ascosporen. Sydowia 37: 75 194, 1985

4) Shibata, T.; M. Nishikawa, Y. Tsurumi, S. Takase, H. Terano \& M. Kohsaka: A new immunomudulator, FR-901235. J. Antibiotics 42: 1356 1361, 1989

5) Ayer, W. A.; Y. Hoyano, M. S. Pedras \& I. I. Altena: Metabolites produced by the scleroderris canker fungus, Gremmeniella abietina. Can. J. Chem. 64: 1585 1589, 1986

6) Suga, T.; T. Yoshioka, T. Hirata \& T. Aoki: ${ }^{13} \mathrm{C}$ NMR signal assignments of herqueinone and its phenalenone derivatives. Bull. Chem. Soc. Jpn. 56: $3661 \sim 3666,1983$

7) CASON, J.; C. W. KOCH \& J. S. CoRreIA: The structure of herqueinone, isoherqueinone, and norherqueinone. J. Org. Chem. 35: $179 \sim 186,1970$

8) Brooks, J. S. \& G. A. Morkison: Naturally occurring compounds related to phenalenone. Part VII. Absolute configuration of atrovenetin and related compounds. J. Chem. Soc. Perkin I 1974: 2114 2119, 1974

9) Narasimhachari, N.; K. S. Gopalkrishnan, R. H. Haskins \& L. C. Vining: The production of the antibiotic atrovenetin by a strain of Penicillium herquei Bainier \& Sartory. Can. J. Microbiol. 9: 134 136, 1963

10) Homma, K.; K. Fukuyama, Y. Katsube, Y. Kimura \& T. Hamasaki: Structure and absolute configuration of an atrovenetin-like metabolite from Aspergillus silvaticus. Agric. Biol. Chem. 44: 1333 1337, 1980

11) Narasimhachari, N. \& L. C. Vining: Studies on the pigments of Penicillium herquei. Can. J. Chem. 41: 641 648, 1963

12) Ayer, W. A.; Y. Hoyano \& M. S. Pedras: Metabolites produced by the scleroderris canker fungus, Gremmeniella abietina. Part 2. The structure of scleroderolide. Can. J. Chem. 65: 748 753, 1987 